\title{
NEWS FROM ERIC
}

\section{AskERIC Update}

Change is the only constant on the Internet and the same is true at the ERIC Clearinghouse on Information \& Technology. The following is a brief summary of some of the changes in the AskERIC Project.

Question-answering activity continues to keep three network information specialists busy. The number of questions received each week ranges from 250-300. OtherERIC clearinghouses are participating more actively in question answering, as AskERIC develops a distributed system for transferring subject specific questions.

The AskERIC Virtual Library has been restructured. The reorganization involved placing the most popular material on the main menu. AskERIC hopes that everyone is pleased with these changes and will continue to provide feedback for further improvements. As always, the AskERIC Virtual Library continues to grow and evolve.

\section{A few of the highlights....}

Thanks to Dr. Liz Liddy and her graduate students in Syracuse University's School of Information Studies, AskERIC now has more than seventy AskERICInf oGuides posted on the AskERIC Virtual Library. AskERIC InfoGuides are subject guides to Internet and ERIC resources of interest to $\mathrm{K}-12$ educators.

AskERIC is also archiving two new listservs on the AskERIC Virtual Library: ISED-L, Independent School Educator's List, and VOCNET, the NCRVE UC Berkeley Vocational Education Discussion List. This brings the total number of listservs being archived by the Virtual Library to twelve.

A new addition to the Frequently Asked Questions (FAQ) directory in the Library is "Goals 2000" information furnished by the U.S. Department of Education. The Goals 2000 information has been very popular, with connections to that directory accounting for approximately one-third of the FAQ directory hits.

On the World Wide Web front, AskERIC, in cooperation with NASA's JPL (Jet Propulsion Laboratory) has placed a two week course guide to accompany on-going shuttle and radar imaging missions. The lessons provided by NASA contained material in the SIR-CED CD-ROM and include some beautiful images. The lessons can be accessed through

WWW/Mosaic using the following URL: http://eryx.syr.edu.
To send AskERIC a question, email: AskERIC@ericir.syr.edu

To access the AskERIC Virtual Library:

with gopher, type:

gopher askeric@ ericir.syr.edu

without, type:

telnet askeric@ericir.syr.edu

login: gopher

\section{Two New ERIC Publications}

Two new monographs published by the ERIC Clearinghouse on Information \& Technology show how education, the economy, and society are being changed by information technology.

An Educator's Guide to Electronic Networking: Creating Virtual Communities by Barbara Kurshan and Marcia Harrington, revised and updated by Peter Milbury, of fers network novices an introduction to the benefits of network resources, a comparison between commercial and non-commercial service providers, and a glossary of network terminology. This guide sells for $\$ 10$ plus shipping.

Christina Doyle's Information Literacy in an Information Society: A Concept for the Information Age, recognizes the change in American society from an industrial based economy toan economy based in services and infornation. This monograph signals the need for educators to prepare students to be successful in this new working environment by teaching students to access, evaluate, and use information from a variety of sources. This eighty page paper sells for $\$ 8$ plus shipping.

Ordering Information: To order the above publications, call Janet LaFrance, Database Secretary, 800-464-9107, or write ERIC Clearinghouse on Inf ormation \& Technology, 4-194Center for Science \& Technology, Syracuse University, Syracuse, New York 13244-4100. Send requests by FAX to $315-443-5448$ or Internet:<janet@ericir.syr.edu>.

AskERIC Project Named Finalist in the 1994 ComputerWorld Smithsonian Awards: Judges Select Technology Applications for their Outstanding Contributions to Society

The AskERIC Project was recognized as one of the most innovative applications of information technology when the ComputerWorld Smithsonian Awards Program (CWSA) announced finalists for its 1994 awards. 
Now in its sixth year, CWSA honors innovative applications of information technology (IT) worldwide and is among the most prestigious program in the computer industry.

Fifty finalists - five in each of the ten categories - were selected from among 279 outstanding applications nominated by chairmen of 100 of the nation's leading IT companies. In each category, an independent panel of three judges, respectedleaders in their fields, chose five finalists and a winner, based on the significant advances the applications have made within their industry."These finalists clearly demonstrate the enormous contributions that technology is making in many aspects of human endeavor," said David Allison, Chief Curator of the Smithsonian Institution's Division of Computers, Information \& Society. "From teachers to business leaders and environmentalists, these finalists are using technology as a tool to solve significant problems and achieve goals unattainable just a few years ago."

The CWSA's 10 categories include Education and Academia; Environment, Energy, and Agriculture; Finance, Insurance and RealEstate; Government and Non-Profit Organizations; Manufacturing; Media, Arts, and Entertainment; Medicine; Science; Transportation; and BusinessandRelated Services. The AskERIC Project was nominated in the Education and Academia category.

"Technology is a powerful tool, and the people who make these applications should be lauded for their immense contributions to society," said Allison. Materials submitted by all finalists will become part of the permanent collection of the Smithsonian
Institution's National Museum of American History. "The Collection of their work will serve as a priceless resource for future generations of researchers."

Finalists were honored, along with the winners, at the CWSA's annual dinner at the National Building Museum in Washington, DC, on June 6, 1994. ERIC/IT Clearinghouse Director, Michael Eisenberg and Director of the ERIC System, OERI, Department of Education, Robert Stonehill, attended the ceremony.

The CWSA Program attracts hundreds of nominations each year. Past winners include applications developed as life-saving medical advances, systems that enable the handicapped to rejoin the work force, and programs that promote literacy and learning in urban schools.

Established in 1989, the ComputerWorld Smithsonian Awards Program was created to search out and publicly honor those men and women who are using information technology, across a broad spectrum of industries, to make our planet a more humane, healthy, and cooperative place to live. In celebrating their achievements, the Program helps to demystify technology and empowers people to use technology as a tool for positive change.

NEWS FROM ERIC is prepared by the staff of the ERIC Clearinghouse on Information \& Technology, 4-194 Center for Science \& Technology, Syracuse University, Syracuse, New York 13244-4100. 315-443-3640.

<eric@ericir.syr.edu> 


\section{ERIC BIBLIOGRAPHY}

Bischof, Phyllis B. (1991, January). Publishing and the Book Trade in Sub-Saharan Africa: Trends and Issues and Their Implications for American Libraries. Journal of Academic Librarianship, 16(6), 340-47. (Available UMI). EJ 421736.

Discusses developments in publishing in Sub-Saharan Africa and suggests implications for American libraries. Highlights include economic constraints; state-sponsored publishing; African authors; publishing in Nigeriaand South Af rica; publishing for children; religious publishing houses; multinational firms; cooperative efforts that offer assistance to U.S. libraries; and acquisitions strategies. (18 references).

de Jager, Karin. (1993, March-June). Electronic Bulletin Boards for South African Libraries. Information Development, 9(1-2), 66-69. EJ 467358.

Discussion of appropriate technology for libraries in South Africa focuses on the use of electronic bulletin boards. Topics addressed include information technology in South African libraries; local library networking; components of an electronic bulletin board; bulletin boards, telephones, and electronic mail; possible uses for a bulletin board; and costs. (Contains three references.)

Grove, Helenvan Ryneveld. Individualisation in the Multicultural Teaching-Learning Situation. (1993). Gifted Education International, 9(1), 59-63. EJ 472673.

This article argues the importance of using an individualized approach in teaching multicultural pupil populations and illustrates this with specific applications made to meet the needs of the culturally pluralistic student population of South Af rica.

Kumbula, Tendayi S. (1993, November). Politics and Education in Zimbabwe: The Country's Transition to Freedom Could Provide Helpful Model for South Africa. Black Issues in Higher Education, 1O(18), 22-26. (Available UMI). EJ 472901.

Changes in the education system of Zimbabwe since the 1940's, principally in the integration and provision of improved opportunities for African Americans, are reviewed. Political factors, integration efforts, teacher education, literacy education, and plans to develop higher education opportunities are noted.

Kumbula, Tendayi S. (1993, September). As Apartheid Falls, BlackEducation Becomes (at Last) a Serious Issue. Black Issues in Higher Education, 10(15) 14-16,18. (Available UMI). EJ 470 992.

A discussion of education in South Africa looks at the history of publicpolicy concerning schools for blacks and whites, enrollment trends since 1969, early efforts at desegregation, and obstacles that must be overcome to make education equitable in that country.
Newa, John M. (1990, June). Libraries in National Literacy Education Programmed in Africa South of the Sahara: The Stateof-the-Art. International Library Review, 22(2), 73-94. EJ 413 596.

Examines the involvement of public and village libraries in literacy and postliteracy programs in Africa south of the Sahara during the last two decades. Issues discussed include the extent of illiteracy in Black Africa, populations served by village libraries, African rural strategies of development, and the implications for library services. (44 references).

Olen, Sandra. (1992). Books and Media for All South African Children in the 21st Century? Paper presented at the Annual Conference of the International Association of School Librarians (21st), Belfast, Northern Ireland, United Kingdom, July 20-24, 1992. 47pp. ED 359960.

This paper identifies obstacles to physical and intellectual access and ef fective use of books and media by South African children and suggests some possible solutions. It also includes a description of a study of the attitudes of first-year student teachers at colleges of education and universities in the Transvaal towards school libraries.

The paper includes nine graphs depicting the findings. Obstacles to access identified in South Af rica are similar to those in other developing countries and include: socio-economic problems, illiteracy, lack of reading tradition, insufficient library facilities or information technology for the majority of the population, few books published locally by black writers in indigenous languages, and few qualified media teachers.

Resources found in South Africa include many wellstocked media centers, some centralized and regional media collections, training courses for media teachers, and programs to encourage reading undertaken by READ Educational Trust (an independent organization) in many of the disadvantaged schools. Ways to make books and media accessible toall children include the redistribution or sharing of resources, community libraries, and cooperation in the development of a national policy for school libraries. Once problems of access are solved, effective use can follow. An example of black traditional literature is appended. (Contains 41 references.)

Overduin, Pierre G. J. (1992). The Role of Children's Books in a Multi-Cultural Society. Paper presented at the Annual Conference of the International Association of School Librarianship (21st), Belfast, Northem Ireland, July 20-24, 1992 13pp. ED 358 850 .

It has been accepted that reading has a pertinent influence on the reader, especially the young reader. In a multi-cultural society, a child learns about himself and the different people around him from books. In this way, the child learns to know and appreciate 
his own culture and that of other children, and a healthy understanding between children near and far can be established; this should also be the case in South Africa. Until the 1970's most children's books in the Afrikaans language have depicted the social order of the time, in which blacks played a subordinate role. Since then, change has gradually taken place, and books have been published in which black and white children live, play, andappreciate each other in a normal way. A positive multicultural attitude in children's literature can contribute, especially in South Africa, to a social change if it corresponds with other reforms toward a more humane and just society. This paper presents a brief history of the founding of South Africa, followed by a description of the many cultures and a list of the twelve indigenous languages. The development of Afrikaans children's books is traced; and problems of current Afrikaans book publishing are detailed, including the limited number of readers, high price per copy, and limited expensive color illustrations.

Rochman, Hazel. (1993, Summer). Against Borders. Journal of Youth Services in Libraries, 6(4), 420-23. (Available UMI). EJ 465819.

Contains a speech from the 1992 American Library Association annual conference where the author and editor, Hazel Rochman, draws upon memories of her South African childhood to describe the effects of apartheid on white South Af rican children andhow this provided the motivation for several books created around a multicultural theme. (seven references).

Van Zijl, Philip. ( 1989). People's Libraries in Support of People's Education. 17 pp. ED 314086.

This paper addresses the planning of information services in South Africa via Peoples Libraries in support of People's Education, i.e., Post-Apartheid education with a humanistic perspective that strives to offer black and white students education with equal levels of quality, and includes Black Studies in the curriculum. People's Libraries are defined as facilities that proactively provide information as well as physical space to assist people in decision making and self-development. It is noted that most libraries that currently fall under that definition are not part of of ficial library and information services. This paper includes a discussion of two potential objectives of People's Libraries: to support labor movements, alternative education programs, and adult education and, in the Post-Apartheid Era, to support and promote reeducation programs on a nationwide scale. It is proposed that services would include storage and dissemination of information in all formats and information referral, and People's Library personnel would be: (1) politically aware, (2) educationalists, (3) managers, (4) organizers, (5) information experts, and (6) willing to perform their jobs for relatively low remuneration or on a voluntary basis. (19 references).

\section{How to Obtain Materials Cited in this Bibliography:}

Citations with ED numbers are documents from Resources in Education. They can be read at a library with an ERIC microfiche collection or ordered, in microfiche or paper copy, from the ERIC Document Reproduction Service, 7420 Fullerton Road, Suite 110, Springfield, VA 22153-2852. Phone: 1-800443-ERIC or 703-440-1400.

Citations with EJ numbers are journal articles from Current Index to Joumals in Education. They can be obtained from a college, university, or public library, borrowed through interlibrary loan, or if so indicated, ordered from: UMI Article Clearinghouse, 300 N. Zeeb Road, Ann Arbor, MI 48106. Phone: 1-800-521-0600.

This bibliography was submitted by Jane $\mathrm{K}$. Janis and prepared by the staff of the ERIC Clearinghouse on Information \& Technology, 4-194 Center for Science \& Technology. Syracuse University, Syracuse, New York 13244-4100. 315-443-3640. <eric@ericir.syr.edu> 